\title{
ESPAÇO E SOCIEDADE NO BRASIL: GLOBALIZAÇÃO E PROJETO NACIONAL.
}

\author{
Pedro Geiger \\ Professor Visitante da UERJ, pesquisador sênior do CNPq. \\ pedro.geiger@gmail.com
}

\section{Resumo.}

O Brasil vem apresentando transformações na sua estrutura econômica, social, geográfica e política,expressivas de sua inserção na globalização. Cita-se o crescimento do PIB, hoje o sétimo mundial; corporações brasileiras transnacionais, investindo inclusive nos EUA; empresas brasileiras disputando o mercado nacional nas formas chamberliniana, indicando graus de sofisticação alcançados nos setores cognitivos culturais da sociedade brasileira; novas territorialidades, compreendendo de um lado, a instalação de infra-estrutura a serviço de corporações, como o pretenso hub de Itaguaí, o terminal portuário de Tubarão, a ferrovia Carajás-Itaqui, e, de outro lado, a formação de grande região cidade global, compreendendo as regiões metropolitanas de Santos, São Paulo e Campinas. Apesar da manutenção de grandes desigualdades de renda, de baixas qualidades ambientais em enormes extensões do espaço urbano, e de recorrentes escândalos de corrupção nos altos escalões da administração pública, não é de se esperar tensões sociais como as que ocorrem atualmente na Europa e nos USA, movidas pela crise econômica. $\mathrm{O}$ discurso pela ascensão do Brasil no cenário mundial soa mais alto.

Palavras chave. PIB brasileiro, corporações transnacionais, sociedade cognitiva cultural, região cidade global, cenário político internacional.

Abstract.

\section{Brazilian Society and its Space: Globalization and a National Project.}

Brazil is presenting large transformations in its economic, social, geographical and political structure, as an expression of its insertion in worldôs globalization. One mentions a number of them. As the GDP growth of the country, currently occupying the seventh place in the world. The fact that some Brazilian corporations are becoming transnational, investing even in the USA. A chamberlain competition of Brazilian enterprises at the domestic indicates sophisticated levels in cognitive cultural sectors of Brazilian society. New territorialities are being built showing, in one side, the establishment of infrastructure in the interest of large corporations, as a pretense hub in Itaguaí, the port terminal of Tubarão, the Carajás-Itaqui railway for mineral transportation. In the other side, one sees the formation of a global huge city region composed by the metropolitan regions of Santos, São Paulo and Campinas. Although a persistent large inequality of income distribution, large urban spaces in environments of very low quality, recurrent scandals of corruption at the high levels of the public administration, one can not expect in a medium term social tensions similar to what goes on Europe and in USA. The discourse for a higher position of the country in the international scenario sounds higher.

Key words. Brazilian GDP, transnational corporations, cognitive cultural society, global city region, international political scenario. 


\section{Introdução.}

O termo globalização expressa uma evolução do sistema capitalista, e que vem instalando um novo quadro mundial, econômico, social, geográfico e político, O uso do termo globalização remete, não só à extensão da superfície terrestre articulada pelos componentes do novo quadro, como a um poder hegemônico adquirido pelas sociedades que assumem a liderança deste movimento.

Uma hegemonia que se apóia no domínio de avanços no meio técnico em geral, e nas áreas que servem de sustentação aos movimentos da globalização, em particular, como a informatização e a instalação de sistema de satélites artificiais. Eles asseguram a coleta e a instantaneidade da difusão da informação por todo o planeta. ñNova economiaò, ñsociedade do conhecimentoò são algumas das designações propostas para caracterizar predicados deste novo quadro presente.

O grau da inserção de um Estado na globalização é avaliado pela dimensão da sua participação neste novo quadro, pelo volume de seus intercâmbios internacionais movidos pelo mesmo, pelas regulações impostas a estes relacionamentos internacionais, e por suas responsabilidades na gestão desta globalização. Como qualquer quadro social, o da globalização suscita manifestações ideológicas e políticas no seio das populações e de seus governantes, favoráveis, ou contrárias.

O exame da posição e do sentido do Brasil na globalização e de sua relação com um possível projeto nacional é precedido por uma caracterização dos predicados e da geografia desta nova economia.

\section{O domínio do capital financeiro e a descolonização do após Segunda Grande} Guerra foram condições imprescindíveis para a realização da globalização.

Nos anos 30, já se desenhava a diferença política entre Estados que centralizavam tanto capital financeiro quanto capital industrial e Estados que centralizavam apenas o capital industrial. O pacifismo anglo americano, fazendo concessões ao apetite hitlerista, expressava, já, a posição do crescente capitalismo financeiro, internacionalista, globalizante, enquanto a Alemanha e o Japão, como genuínos representantes do capitalismo industrial nacional, foram capazes de ascender a Guerra de 1939/1945.

A vitória aliada se deveu fundamentalmente á capacidade industrial norte-americana e à resistência soviética. Seu resultado significou, de um lado, a imposição da hegemonia 
do país capitalista dotado de alta capacidade produtiva, tecnológica, e financeira; e de outro lado, a sobrevivência e a retomada dos ideais marxistas em esferas estatais. Significou também um início do desmanche dos históricos impérios colônias.

Depois da fase da reconstrução das áreas destruídas pela Guerra, na Europa e na Ásia; e das instalações da chamada sociedade da afluência e do Estado previdenciário, ou, do bem estar, seguiu-se, a partir dos anos 70, o ciclo do chamado neoliberalismo. Este ciclo compreendeu enorme expansão do capital financeiro, fundado inclusive no jogo especulativo inventado nos USA, o dos derivativos, criando uma economia virtual e que se foi espalhando pelo mundo. Nesta fase se intensificou, também, a localização nos países periféricos de estabelecimentos industriais das gigantescas corporações com sede nos países centrais, e que se tornavam transnacionais. Estas empresas levavam empregos da economia real para a periferia e contribuíam para a enorme intensificação do comércio internacional, criando referência para a especulação financeira e dinamizando o movimento da globalização. A especulação financeira, antes da atual crise econômica, chegou a fazer circular pelo mundo, diariamente, trilhões de dólares.

Era necessário, no entanto, que fossem abertos os espaços coloniais, fechados pelo monopólio das metrópoles imperiais, para a livre circulação dos capitais. Depois da Segunda Grande Guerra, USA e a antiga União Soviética convergiram para a extinção do histórico regime colonial interessados em estender a sua influência e coerentes com os seus ideários,. O Reino Unido, mais integrado nos novos tempos, teve saída mais fácil de suas colônias de ocupação, do que a França.

No era das transnacionais e da grande expansão do capitalismo financeiro, e considerando a dissuasão atômica, a guerra entre grandes potências hegemônicas parece descartada no momento.

\section{Predicados da globalização.}

\section{- O enlace entre ciência, tecnologia e estética com todas as instâncias sociais.}

A nossa mídia lança diariamente enorme quantidade de informações sobre o quadro econômico, financeiro e social do Mundo e do Brasil. O entendimento pleno destas informações já em si, exige um nível de conhecimentos bastante elevado. Torna-se fácil compreender que, na atualidade, governar o Estado, ou dirigir uma corporação exige massa altamente sofisticada de saberes e uma infra-estrutura provedora de um complexo 
conjunto de informações quantitativas e qualificativas. É o que caracteriza a chamada ñsociedade do conhecimentoò, ou ñcognitivo-culturalò(SCOTT, 2012).

Esta necessidade é uma das razões que explica a transformação da empresa pessoal em corporação e a relação crescente entre Estado, empresas, Universidade e instituições acadêmicas de pesquisa. Explica também o perfil do capital humano das grandes empresas privadas e estatais e dos órgãos superiores de governo com os seus quadros de executivos: presidentes, ceo's, diretores, gestores do capital dotados de conhecimentos especializados.

Corredores foram estabelecidos, os executivos circulando entre governos, agências públicas internacionais, como o FMI, a OMS, a FAO, grandes empresas privadas, e a Universidade. Foi o caso no Brasil de Pedro Malan, Armínio Fraga, Carlos Lessa, Luciano Coutinho e outros. O mundo de hoje passa a ser dirigido por estas figuras híbridas, como Barack Obama, formado em Harvard, Dilma Roussef, economista e Presidente do Brasil. Mário Monti, professor universitário de Economia e novo primeiro ministro da Itália. Como foi Fernando Henrique Cardoso, professor de Sociologia e presidente do Brasil.

O enlace de ciência e de tecnologia com todas as outras instâncias, ou sistemas de práticas sociais, acompanha o homem desde o seu surgimento. No clássico A Questão Agrária, Kautsky tratou da introdução de ciência na agricultura desde o início do capitalismo. Quanto à forma corporativa, note-se que a primeira, o grupo City, surgiu em 1812, quando Napoleão invadia a Rússia. American Express, americana, e a Tobacco, inglesa, apareceram nos meados do século 19. No entanto, a história apresenta a penetração crescente, constante, cada vez mais sofisticada no real. Os predicados da globalização incluem a introdução de novos entes, de coisas que passaram a dominar o cenário, como as naves interplanetárias. A multiplicação, transnacionalização e dimensão das corporações se intensificaram na fase da globalização, iniciada nos anos 70.

\section{- Nova estrutura social e de classe, novas formas competitivas.}

A expansão contemporânea das corporações transnacionais e de outras formas de atividades empregando capital humano de alta qualificação tem conduzido a novas composições de estrutura social. Utilizando, por afinidade eletiva, nomenclatura de Michal Kalecki, que a aplicou para distinguir departamentos de comércio internacional, 
sugere-se nova divisão em classes sociais, com capitalistas, capitalistas assalariados e assalariados.

Capitalistas assalariados seriam os Ceo's e diretores das empresas privadas, os altos executivos de setores públicos, auferindo altos rendimentos e prêmios. Como quaisquer assalariados, podem perder o emprego, como aconteceu recentemente com Agneli, que foi presidente na Vale. Como capitalistas traçam as políticas e estratégias das empresas, estabelecem os quadros e as remunerações dos assalariados. Henri Lefébvre propôs que o termo capitalista fosse definido simplesmente por um nível de ativos possuído.

Um predicado que caracteriza a nova economia, é a competição de forma chamberliniana de certos setores de empresas, isto é fazendo valer a sua marca e não o preço. Por exemplo, enquanto supermercados e lojas de equipamentos domésticos, como o Prezunic ou as Casas Bahia, colocam os preços de suas mercadorias em seus anúncios na TV, as Havaianas ou a Rider, apenas apresentam o meio social que faz uso de suas sandálias, a estética de seus produtos..

Outro aspecto da nova economia mostra o surgimento de novos empreendedores a partir de áreas universitárias ou de periferias sociais urbanas, de pessoas que passam a integrar a chamada sociedade cognitivo-cultural e que atuam com as denominadas indústrias criativas. No caso da música popular brasileira, por exemplo, a partir dos meados do século passado, verificou-se a participação de artistas das classes mais altas, como Vinicius de Morais, Tom Jobim, Chico Buarque, Caetano Velloso. Agora, na atualidade, o que se vê são jovens favelados do Rio de Janeiro criando orquestras que executam musica erudita, e outros conseguindo lugar em conjuntos internacionais de opera, ou balé.

\section{- Novas territorialidades e regionalizações.}

No que tange a temas geográficos, a globalização se acompanha de novas territorialidades e regionalizações.

Em termos territoriais cita-se a instalação de infra-estrutura que atende particularmente à economia corporativa, como linhas ferroviárias para transporte de minérios, terminais portuários especializados, hubs. Nestas condições, a antiga articulação entre função portuária e desenvolvimento urbano se esmaece. No transporte ferroviário, o trem bala revela uma outra face da nova estrutura social e geográfica.

A valorização do tamanho grande da área territorial dos países não é nova. Já no começo do século 20, o poder americano expressava a condição de uma economia 
nacional industrial desenvolvida, em escala continental. Depois, foi a vez da antiga União Soviética. Hitler tentou o mesmo, através de realizar uma Europa colonizada pela raça ariana. Agora, o valor da escala é exposto na ascensão de potências emergentes, do BRIC e na constituição da União Européia.

A grande escala também se manifesta na formação da chamada região-cidade global, uma superposição de aglomerações urbanas, incluindo uma ou mais regiões metropolitanas.

No entanto, a flexibilidade da globalização, ao integrar movimentos novos e antigos, se manifesta também em fragmentações e desconcentrações geográficas. Pequenas unidades políticas também alcançam funcionalidades atuais particulares, como é o caso de Cingapura, cidade Estada, de Hong Kong, com estatuto especial, na China, dos paraísos fiscais do Caribe. A região-cidade global, um novo formato regional, compreende tanto a desconcentração, a partir de um, ou mais grandes núcleos, como uma nova aglomeração, nos limites do espaço da região cidade.

\section{- Em conclusão.}

Concluindo, o movimento da globalização compreendeu novas divisões sociais recobrindo divisões antecessoras. Como a divisão entre um setor corporativo, com seus inter-relacionamentos e espaços geográficos próprios, de acumulação mais voraz, e os setores não corporativos. Ou, a divisão entre um setor de trabalho qualificado e um setor não qualificado. Este movimento tem provocado movimentos contraditórios quanto a manutenção, diminuição, ou aumento da distribuição de renda, segundo locais e momentos de tempo. Em termos regionais, certamente provoca aumento, uma vez que faz distinguir entre regiões mais dinâmicas e regiões estagnadas. No entanto, desde que a tendência seja de aumento da população das regiões mais dinâmicas, e diminuição nas regiões estagnadas, o sinal pode variar, de acordo com uma conjuntura, para a população de um país como um todo. .

\section{Crise e tensões.}

\section{- Movimentos anti-sistêmicos acompanham a globalização.}

Como qualquer quadro social, o da globalização passou a suscitar manifestações ideológicas e política, favoráveis e desfavoráveis, no seio das populações e governantes de Estados. Manifestações que miram quer a organização interna dos países, quer as relações internacionais influenciadas pela globalização. . 
Nos países do Centro, movimentos contrários à globalização vinham ocorrendo em setores ultra-direitistas, nacionalistas e em setores das esquerdas de orientação marxista, anti-capitalista.

Setores da esquerda marxista, denominados de ñmarxismo ocidentalò, crítica do socialismo real praticado na antiga União Soviética e nas Repúblicas Populares da Europa Oriental e Central, defensores de direitos civis fundados no humanismo prescrito por Marx na Ideologia Alemã, vêm tendendo para uma social democracia capitalista. Enquanto setores inspirados no chamado ñmarxismo orientalò (LOSURDO, 2011) defendem regimes estatizantes e autoritários, quer sejam favoráveis à globalização, como a China, ou contrários à ela, como o Irã. Desde que se posicionem contra o ñcolonialismoò. (No sentido leninista, não no sentido histórico relacionado aos antigos impérios coloniais), apontado como a contradição maior, no plano global.

Nos países periféricos, os movimentos anti-sistêmicos vinham ocorrendo pelas mesmas razões, nacionalismo, anti-capitalismo, mas, fermentados pela herança cultural anticolonialista, presente mesmo entre as massas menos politizadas.

Em países muçulmanos, atitudes anti-capitalistas e anti-globalização de grandes massas de suas populações se nutre da tradição cultural religiosa, contrária à ocidentalização e às suas permissividades e valores.

Nestes países, de longa tradição moral, em um passado recente, regimes laicos militares, como o de Nasser, no Egito, ou de Khadafi na Líbia, foram implantados com vistas à modernidade. Depôs de dizimaram quadros da esquerda que os ajudaram a se instalar, estes regimes se entregaram à corrupção, abrindo caminho para o fundamentalismo religioso. Nos países onde o fundamentalismo islâmico alcança o poder, o governo praticamente fecha o país à globalização, caso do Irã.

O apoio político de Estados laicos emergentes a países onde o fundamentalismo religioso tomou o poder, ou onde se instalaram regimes fechados a práticas democráticos, se inscreve na ñrealpolitikò. O apoio político por movimentos sociais de esquerda segue a lógica de que ño inimigo do meu inimigo é meu amigo, ou de que ños fins justificam os meiosò.

\section{- A reviravolta entre emergentes.}

Em países periféricos emergentes, onde a esquerda alcançou o poder, desde que a articulação com a globalização tenha passado a oferecer ganhos de crescimento do PIB, 
o discurso anti-sistêmico, ou anti-capitalista, de governantes e setores da esquerda, vem mudando de tom e de conteúdo.

O caso da China é sui generis. Primeiro, porque lá o Partido Comunista conseguiu liderar uma revolução armada desde os anos 20, conquistar o poder em 1949 e se manter no mesmo, até os dias atuais. Segundo, porque no plano das relações internacionais, a China não apenas participa da globalização, como se tornou um pilar de sustentação da economia globalizada.

A China se tornou o maior receptor de capitais de capitais do Mundo aplicados em atividades produtivas, passando a apresentar até recentemente crescimento anual do PIB na ordem de dois dígitos. Mesmo atualmente o seu crescimento se realiza a cerca de 9\%. A China se declara caminhar para um ñsocialismo de mercadoò, isto é, onde os potenciais criadores, empresariais e individuais, se encontram no termo mercado, e a presença de um Estado provedor de infra-estrutura, que suplementa a economia, e regulador se encontra no termo socialista. (ZEMIN, 2002).

No Brasil, outro grande receptor de estabelecimentos industriais de capital estrangeiro, se verificou ganhos, obtidos pelo alargamento do seu espaço na globalização, em termos dos volumes de produção e qualificação de setores de sua população. No Brasil, cujo governo atual é dirigido por partido de esquerda e com muitos marxistas nos quadros dirigentes do país, o abandono do discurso anti-globalização também se encontra em curso. O lema oficial atual sendo ñum país rico e sem misériaò. ñPaís ricoò se refere a mercado, ñsem misériaò, a Estado. No Brasil, como na China, fazer ñcrescer o boloò, frase nossa conhecida, é prioritário.

\section{- A crise atual.}

Ao fim do ano 2008 começou a se desenhar nos EUA o começo de uma crise financeira, que se foi tornando cada vez mais profunda até envolver presentemente todo o mundo globalizado.. Uma crise que vem sendo comparada, por sua amplitude, duração e efeitos, à crise dos anos 20 e 30, e que desembocou na Segunda Grande Guerra.

A crise começou na forma de um chamado ñestouro da bolhaò criada no setor do financiamento do mercado habitacional. O efeito dominó passou a afetar toda a economia do sistema mundial globalizado, atingindo vigorosamente, tanto os setores financeiros, como os setores produtivos, particularmente nos Estados Unidos, Europa e Japão. A consideração da crise a pior desde a dos anos 20 e 30, leva em conta a sua 
duração, já de 3 anos, o montante de trilhões de dólares de capital evaporado, o recuo da produção econômica, com o conseqüente aumento do desemprego e do alto endividamento dos Estados, levando-os a recuar de funções assistenciais e gerando agravamento de pobreza na população.

Com a instalação prolongada da crise, a tensão estabelecida pelas divisões mencionadas anteriormente, nas sociedades atuais, se agravou pela expulsão de pessoas do setor qualificado para o setor não qualificado, através do desemprego. Em todas as partes do mundo, em grau maior ou menor, e de formas diversas, a tensão social tem crescido. (È possível encontrar laços inclusive entre os movimentos da chamada ñprimavera árabeò, sobre os quais a dimensão deste trabalho não permite elaborar).

Num país como os Estados Unidos, a renda per capita havia se tornado a mais elevada do mundo, e a população instruída e qualificada já formava grande parte da população. Ocupações não qualificadas passavam a ser preenchidas por imigrantes legais e ilegais provenientes de países periféricos. Maior aumento da desigualdade de renda passara a se instalar com o neoliberalismo, e com a saída de estabelecimentos industriais para o exterior.. iria influir de forma decisiva para uma evolução negativa geral do sistema. Este quadro iria agravar a evolução da crise nos EUA.

A crise é maior na Europa porque lá o Estado previdenciário alcançara larga dimensão o que se reflete nas contas públicas, tornadas deficitárias em graus elevadíssimos. Nos Estados Unidos, a medicina social para todos ainda se encontra na fase de projeto.

\section{- A procura de solução para a crise.}

À diferença da crise dos anos 20 e 30, quando cada país procurou uma saída própria, Roosevelt instituindo o New Deal, na linha keynesiana, Hitler militarizando a Alemanha para gerir os bens europeus, atualmente os países do Centro buscam uma solução colegiada. Mais do que isso, os emergentes são chamados a colaborar para a saída da crise. Países como a China, a Índia e o Brasil, antes periféricos, ou colônias, comparecem com grande voz ativa, em fóruns internacionais, como os do G-20, e são instados a empenhar recursos para ajudar a financiar dívidas de países europeus mais expostos, sustentando um sistema no qual passaram a ter interesses.

Invariavelmente, a solução dos países do Centro, governados por partidos de direita, ou de esquerda, é cortar gastos públicos, o que contribui para a manutenção de altas taxas de desemprego, e ampliando ainda mais a tensão social. Particularmente na Europa onde 
ganhos obtidos pela instituição do Estado previdenciário estão sendo perdidos por grandes cortes na despesa pública. significam perdas na assistência social.

\section{- Manifestações nas ruas contra o sistema.}

Na Europa e nos Estados Unidos começaram a se manifestar movimentos de massas urbanas em protestos de rua. Na Grécia, ameaçada de falência, o Estado tendo perdido a condição de manter o fluxo de caixa, teve de aceitar medidas muito duras para receber empréstimos do Banco Central da EU. Manifestações violentas de rua se tornaram rotineiras, o primeiro ministro, político socialista, resignou, sendo substituído por um tecnocrata. Na Espanha, onde a taxa de desemprego chega a 20\%, os manifestantes se intitularam de ñindignadosò, termo que passou a ser utilizado para todos os outros. $\mathrm{O}$ movimento de ocupar Wall Street, em Nova York atingiu grande repercussão.

Estes movimentos de protesto, até o momento, não adquiriram uma definição política clara, não formalizaram um ideário e um roteiro de medidas de governo. O que muitos cientistas sociais observam é que eles testemunham uma certa falência em andamento do regime de partidos políticos. .

No Brasil de hoje, integrado na globalização, a tensão entre distintos setores sociais, também, se vem manifestando, Aqui já existe um grande setor corporativo, hegemônico, formando um setor distinto dos outros presentes na sociedade brasileira. Contudo, não é de se esperarem nosso país, pelo menos para breve, protestos sociais de massa. Apesar do Brasil apresentar um rico passado de movimentos sociais ideológicos e políticos ostensivamente anticapitalistas e antiglobalizantes. Em primeiro lugar porque, até o ano passado, a crise global não afetou, o crescimento econômico. A desaceleração verificada no ano presente não chega a ser dramática. Depois, é necessário considerar que os movimentos sociais no Brasil visavam uma liberação de um dito colonialismo. Este estaria sendo vencido pela atual emergência econômica do país, enquanto membro da globalização. Ou seja, colocava-se, como se coloca agora, a relação centro-periferia de Estados como sendo a contradição principal, e, em segundo plano, as diferenças sociais internas, Fazendo lembrar a teoria maoísta. .

O novo ciclo de crescimento e de desenvolvimento brasileiro. $O$ ingresso do Brasil na globalização

\section{- Antecedentes e fase de transição.}


Durante a crise mundial dos anos 20 e 30, em seu primeiro governo (1930-1945), inspirado no fascismo europeu, e no centralismo histórico brasileiro, Getúlio Vargas instaurou um Estado autoritário e interventor nas atividades econômicas e aplicou um modelo de desenvolvimento fundado em industrialização e urbanização. No entanto, a entrada dos Estados Unidos na Segunda Grande Guerra obrigou Getúlio a mudar de rumo e colocar o país ao lado dos países da democracia capitalista, Estados Unidos e Inglaterra; e também da antiga URSS. (Pearl Harbor ocorreu em 7 de dezembro de 1941, antes, em julho do mesmo ano a Alemanha nazista invadira a União Soviética).

Durante o desenvolvimentismo do governo JK (1955-1960), os vínculos com o capitalismo cresceram com a entrada de empresas estrangeiras industriais, tendo sido estabelecido o setor da produção automobilística. Enquanto o palácio presidencial recebia intelectuais da esquerda e de comunistas, e recorria a seus serviços, como os de Portinari, Oscar Niemayer e Darci Ribeiro.

O desenvolvimentismo compreendeu grandes mudanças no quadro geográfico nacional, como a aceleração do distanciamento de São Paulo como principal pólo concentrador, econômico e demográfico; a mudança da capital federal para a Brasília e a abertura de vias para a maior ocupação da Amazônia. São Paulo passou a exercer, progressivamente, maior papel, tanto na organização dos trabalhadores, como na de uma burguesia nacional, e consequentemente, na política em geral.

Nos anos 60, o clímax da Guerra Fria atinge o auge com o episódio dos mísseis em Cuba, em 1961. A partir daí, seria iniciada uma fase internacional de distensão lenta entre USA e URSS. Porém, em 1964, o confronto é ainda muito vivo, e considerando que havia também uma China em crescimento. No Brasil, João Goulart inicia aproximação com a China Comunista, e se amplia a circulação palaciana de setores de esquerda. Propõe passos de reformas na estrutura econômica e social do país. Do outro lado, a crescente burguesia paulista e um de seus porta vozes intelectuais, Roberto Campos, querem modernização, no sentido de instaurar ñum verdadeiro capitalismoò que o país não desfrutava (Houve um famoso debate Carlos Prestes/ Roberto Campos). O confronto terminou no golpe de 1964. O clima de guerra fria e o quadro político da época ainda permitiam certa interferência americana de apoio. A influência do clima internacional pode ser reconhecida pela instalação de regimes militares por todo o continente sul americano. 
O governo militar manteve a abertura do país para os investimentos industriais estrangeiros, criou novas escalas para as empresas dos serviços públicos, ampliou em número e dimensões as empresas estatais, apoiou o crescimento do empresarial privado nacional, montando uma estrutura chamada de tripé (por Raymundo FAORO 1975).Não se tratava, porém, ainda, de uma abertura do mercado brasileiro nos moldes da globalização. A conversão cambial não era livre, o valor do câmbio era fixado pelo governo, não era permitida a presença de bancos estrangeiros, e era grande a proteção aduaneira para a produção doméstica. Os militares seguiam na linha nacionalista que os fez apoiar Vargas no passado. No governo Geisel, com a crise do petróleo de 1973, inclusive ampliaram medidas protecionistas e estatizantes, como por exemplo, criar mercados cativos para a indústria nacional, no caso das compras governamentais, ou na formulação de Planos Trienais.

A dificuldade de ajuste do regime militar à globalização que se estendia, a exaustão econômica do regime e uma inflação crescente, contribuíram para a sua extinção em 1984.

\section{- Três marcos de um novo ciclo: Mercosul (Sarney). Plano Real (FH) Bolsa Família e Salário Mínimo (Lula).}

A redemocratização trouxe um período de hesitações e tentativas no campo da política econômica, de 1985 a 1994. Esta década e a última do regime militar têm sido chamadas de ñas décadas perdidasò, Contudo, a redemocratização, generalizada na América do Sul, permitiu que neste período, durante o governo José Sarney, foram dados os passos para a formação do Mercosul, um exemplar dos novos entes geográficos socialmente construídos pela globalização.

Se Sarney, como Tancredo Neves, eram figuras do setor tradicional conservador da política, no entanto, os corredores palacianos passariam a ver, logo, a circulação de pessoas de passado marxista, ou embuidas do chamado ñmarxismo ocidentalò. Foi o caso de Fernando Henrique e de membros da equipe econômica que elaborou o Plano Real, em 1994.

Em si mesmo, o Plano Real consistiu num realinhamento comum dos preços de todas as mercadorias num mesmo momento, Para manter o valor da moeda e domar a inflação, a partir deste momento, o Plano foi escorado numa série de medidas fundamentais, a serem cumpridas em todos os níveis de governo.. O superávit fiscal significou receitas acima das despesas. A responsabilidade fiscal significou prever a fonte de recursos 
para qualquer despesa. A abertura do mercado para as importações serviria como arma contra a inflação, ao introduzir mercadorias mais baratas que as produzidas no Brasil. As privatizações de empresas estatais deveriam tirar o ônus das deficitárias sobre as contas públicas e, de modo geral, servir às suas capitalizações, inclusive com aportes estrangeiros, e aumento de investimentos. O avanço da telefonia no país é um episódio citado com freqüência.

A oposição da esquerda petista nacionalista, anti-americana e, então, anti-globalização, ao Plano Real clamava para o perigo da desindustrialização do país, ante a abertura para as importações. No entanto, as habilidades do empresariado nacional e de seus executivos foram demonstradas quando ele aproveitou a abertura para reequipar, modernizando, o seu parque industrial e competindo mesmo no mercado internacional. $\mathrm{Na}$ atualidade, vê-se o grupo Gerdau abrindo usinas siderúrgicas nos USA, a Embraer vendendo seus aviões de porte médio para diversos países e investindo na China, a estatal Petrobrás atuando em diversos países, etc.

O fato é que a partir dos meados dos anos 90, teve início um novo ciclo de crescimento brasileiro com expansão de suas corporações privadas e estatais. Expansão que se ampliou durante o governo Lula, com o PT realizando uma inflexão e passando a apoiar, de certo modo, a continuidade dos princípios que nortearam o Plano Real. Aliás, o sistema constitucional democrático brasileiro tem imposto um quadro político no qual o governo é obrigado a realizar alianças com partidos conservadores em prol da governabilidade.

O governo Lula, porém, contribuiu para ampliar mudanças no plano social interno. Considera-se que os aumentos anuais, acima da inflação, do salário mínimo, mais do que o bolsa família, influi para pequena melhoria observada na distribuição da renda.

Considera-se também que o aumento do consumo devido a estes benefícios influiu para amenizar a crise mundial iniciada em 2008.

Evidentemente, que medidas desta natureza não alteram o caráter do regime econômico e social, mas, importam para o estabelecimento de novos sentimentos de identidade. Dispor de um cartão oficial para receber o bolsa família retira o beneficiado da massa amorfa e o insere numa determinada classe social do capitalismo. Com frequiência se substitui a categorização da população economicamente ativa brasileiro, PEA, segundo número de salários mínimos recebidos, por uma categorização que define uma qualificação social, que vai de A a E.

Geo UERJ - Ano 13, nº. 22, v. 2, 2º semestre de 2011 p. 272-289 - ISSN 1981-9021 http://www.e-publicacoes.uerj.br/index.php/geouerj 
A aproximação maior, brasileira, à globalização, promovida por Fernando Henrique Cardoso, e continuada pelos governos do Partido dos Trabalhadores, de Lula e de Dilma Roussef. se manifesta atualmente no plano internacional, o país reivindicando maior participação na direção do sistema, propondo mudanças nas formas de gestão do sistema econômico, e solicitando inclusive assento permanente no Conselho de Segurança da ONU. O Brasil aumenta a sua voz quando é instado a ajudar com recursos financeiros no combate à atual crise mundial econômica e financeira.

\section{- Alguns predicados da globalização no Brasil.}

O Brasil se coloca como a quinta economia mundial, com o PIB em torno de dois trilhões e duzentos bilhões de dólares, atrás dos USA, União Européia, China e Japão. Acumula reservas da casa de 300 bilhões de dólares. Faz parte dos grandes emergentes, formando o chamado BRIC, Estados de dimensão continental ou subcontinental, com populações de 150 milhões para mais, e em grande crescimento industrial. Ocupa posição de liderança em seu continente, sendo um dos líderes do G-20, o grupo de países que busca ima atuação de gestão coletiva dos problemas mundiais.

Um predicado particular, é que ao contrário da China e Índia, o Brasil é auto-suficiente em termos de alimentar a sua população e ainda figura como grande exportador de commodities agrícolas in natura e industrializados.

O Censo Demográfico de 2000 já mostrava que cerca de 14,3\% da PEA brasileira se encontrava nas ocupações de membros superiores do poder público, dirigentes, dirigentes de organizações de interesse público e de empresas, e gerentes, bem como, nas ocupações de profissionais das ciências e das artes, e auferindo mais de 20 salários, Eles correspondiam a cerca de $65,0 \%$ da PEA que recebia tal valor. No Sudeste se encontravam $62 \%$ desta população, No Sudeste o contingente da PEA nas ocupações mencionadas e auferindo mais de 20 salários se elevava, para 21,3\% e representava 70,8 de todos que ganhavam tal soma. Ou seja, na periferia, se localizava proporcionalmente menor número de pessoas com os maiores rendimentos sendo obtidos de ocupações que melhor caracterizam a sociedade do conhecimento.

Em termos geográficos, novas territorialidades mostram a implantação de infraestruturas a serviço da economia corporativa, como a ferrovia de Carajás a Itaqui, terminais portuários como o de Itaqui, ou de Tubarão, o hub de Itaguaí, na baía de Sepetiba. As grandes hidrelétricas, que atendem os estabelecimentos e os lares se deslocam para mais longe do núcleo central brasileiro, para a Amazônia. 
O forte centralismo histórico brasileiro, que a República herdou do Império, ainda impede autonomia financeira maior dos estados da Federação. No entanto, a figura do estado como unidade política e social tem crescido, enquanto que a macro-região tão em voga na época da ditadura perde presença. Ganham presença as aglomerações urbanas, a superposição metropolitana de São Paulo e Campinas.

\section{Tensões.}

\section{- ñAndar de cimaòe ñandar de baixoò a herança histórica.}

Uma divisão social do Brasil em dois setores, chamados do ñandar de cimaòe do ñandar de baixoò antecede uma divisão contemporânea em formação e que passa a definir setores de qualificados e de não qualificados. A divisão tradicional ainda possui força de permanência, mas vem sendo erodida por movimentos, cada vez mais fortes, particularmente de jovens instruídos que passam do ñandar de baixoò para o setor qualificado. Enquanto que pessoas de gerações mais antigas, do ñandar de cimaò permanecem em número expressivo no setor não qualificado.

São associadas à divisão tradicional permissividades de costumes, como o nepotismo, mordomias para servidores públicos, a cumplicidade entre as diversas camadas sociais na prática de corrupções, a impunidade de crimes, particularmente de membros do ñandar de cimaò, e a excessiva burocracia, aliada à herança bacharelesca. Estas permissividades se alimentam umas das outras, se refletem do setor de cima para o setor de baixo, e vice versa, e criam um estado de tensão latente.

Estas permissividades resultam de um lastro histórico em que contam: a colonização inicial em um vasto território por um Estado relativamente fraco com grande dispersão da população. A questão de massas de população sem registro civil, ou seja, legalmente inexistentes ainda está sendo atacada pelo governo federal. Conta-se ainda a natureza latifundiária da economia dominante inicial, o regime aristocrático e escravocrata da monarquia que durou 4 séculos, a república estando instalada apenas mais de um século, e a rapidez da urbanização. Em 1940, era getulista, a população urbana era de $32 \%$ da população total e 60 anos depois, passava de $80 \%$. Ou seja, a população atual contém, simultaneamente, gerações oriundas de um outro Brasil, de um outro momento cultural, muito diferente do atual. Por outro lado, o populismo encontrou ambiente propício nesta rápida urbanização e se tornou uma fonte de cumplicidade em aspectos negativos, como os acima apontados, entre os dos andares de cima e de baixo. 
Tal quadro ajudou a manter imobilismos em várias áreas, como o forte centralismo brasileiro, hoje sob critica crescente.. Note-se que enquanto a polícia uniformizada em metrópoles como Nova York, é sujeita às autoridades locais, no Rio de Janeiro e São Paulo a Polícia Militar é da esfera estadual, herança do Brasil agrário mercantil. No Brasil, o bacharelismo mantém separado, na área civil, a justiça comum, a justiça trabalhista e a justiça eleitoral, impensável nas economias industriais desenvolvidas.

Até recentemente, as novas gerações instruídas, e que representavam pequena fração da população, depois das retóricas reformistas, enquanto estudantes, se ajustavam a estes quadros interessados em suas carreiras pessoais. No entanto, o grande aumento que se verifica no corpo discente universitário atual, inclusive com número crescente de jovens das camadas de baixa renda, obrigará certamente que as questões de mérito ocupem um lugar mais alto na sociedade brasileira. Um dos caminhos a superar as permissividades negativas. São muito jovens aqueles que se manifestam hoje nas ruas do Brasil, por questões morais.

\section{- A prevalência da ideologia do crescimento econômico.}

$\mathrm{Na}$ atualidade, porém, como já mencionado, a questão ñcolonialò, parente da teoria da ñdependênciaò (OLIVEIRA, Francisco 2003), ocupa o primeiro plano, tirando maior atenção de questões internas. Apenas a questão ambiental e os direitos dos povos da floresta, ou a questão dos direitos humanos, mobiliza movimentos sociais e Ong's. No entanto, deve ser observado que estas questões se articulam com a questão ñcolonialò. Há a idéia de desejos intervencionistas internacionais pela ocupação da Amazônia, com pretextos ambientalistas, de modo que um movimento doméstico, ambientalista e a favor dos povos da floresta, tiraria tais argumentos.

Todas estas questões nacionais são agora recobertos pela divisão entre, de um lado, um setor econômico e social, corporativo, privado e estatal e de setores que com ele se articula; e de outro lado, os setores tradicionais da economia e setores populares. A disputa aparece de diversas maneiras, como por exemplo na repartição dos orçamentos, entre investimentos que atendem mais a ima parte ou a outra. Aparece também nos debates sobre questões morais e ambientais. No entanto mais uma vez, estas disputas não chegam a ocupar o plano principal do embate político, pela razão já exposta. Prevalece de certo modo que o ñfim justifica os meiosò. 


\section{Palavras Finais.}

Foi dito que o mote do governo brasileiro atual é o de um país rico e sem miséria. Ele como que reflete, virtualmente, um projeto nacional atual, embora não formalmente formulado.. Não é um projeto revolucionário de luta de classe, é mais próximo do reformismo. Note-se que em pesquisa recente com os membros do Partido dos Trabalhadores, apenas $30 \%$ declararam sua orientação esquerdista, a maioria se disse nacionalista. Dada a natureza de nosso regime político trata-se mais de um mote de governo do que do Estado, diferente do que ocorre na China Comunista, no presente.

Este mote possui também a força de atender ao interesse da manutenção da globalização, Tem sido dito que a crise em 2009 e 2010 foi mais suave no Brasil, em parte, devido a políticas salariais que reduziam a desigualdade de renda e sustentavam o consumo. No entanto, importante tem sido o grande aumento do comércio com a China, no contexto da economia globalizada.

O comportamento brasileiro e chinês neste período de crise, a responsabilidade que vem sendo assumida de forma coletiva pelos Estados para enfrentar a crise, são aspetos que fazem crer num novo ciclo mundial. Um ciclo caracterizado pela maior presença estatal, reguladora de uma permanência de economia de mercado, no qual gestores, executivos, capitalistas assalariados, ou qualquer outro nome que se queira dar, assumem as rédeas do poder. Resta ver como reagirão os revolucionários de sempre.

\section{Pequena Bibliografia.}

BENKO, Georges, Mundialização econômica, metropolização do Mundo, Revista do Departamento de Geografia, Salvador, UFBA, ${ }^{\circ}$ 15:45-54, 2000.

CASTRO, Iná E., Geografia e Política, Território, Escalas de ação e suas Instituições. $1^{\mathrm{a}}$ ed. , Rio de Janeiro, Bertrand Brasil, 2005.

FAORO, Raymundo,.Os Donos do Poder, $2^{\mathrm{a}}$ edição, São Paulo e Porto Alegre, EDUSP.e Editora Globo, 1975

HARDT, Michael, e NEGRI, Antônio, Império, Rio de Janeiro, Record, 2001 Multidão, Rio de Janeiro, Record, 2004.

IBGE, Censo Demográfico de 2000. Rio de Janeiro.

KALECKI, Michal, Teoria da dinâmica econômica, Os Pensadores, v. XLVII, São Paulo, Editora Abril, 1970.

KAUTSKY, Karl, A Questão Agrária, São Paulo, Nova Cultura, 1986. 
LIMONAD, E., HAESBART, R. e MOREIRA, R, org., Brasil Século XXI, Por uma Nova Regionalização, São Paulo, Editora CNPq, 2004.

LOSURDO, Domenico, Como nasceu e como morreu o ñmarxismo ocidentalò. Página digital do Centro Humboldt n ${ }^{\circ}$ 1107, 2012.

MARX, Karl, e ENGELS, Frederic, A Ideologia Alemã. São Paulo, HUCITEC, 1996.

MEZÁROS, István, Estrutura Social e Forma de Consciência. II, A Estrutura Dialética da História, São Paulo, Boitempo Editorial, 2011.

OLIVEIRA, Francisco, Crítica à Razão Dualista, O Ornitorrinco, São Paulo, Boitempo Editorial, 2003,.

SCOTT, Allen J. As Cidades da Terceira Onda, no prelo, em Globalização, Políticas Públicas e Reestruturação do Espaço, livro promovido pela Pós Graduação da UERJ. TAYLOR, Peter J, org., Political Geography of the Twentieth Century: a Global Analysis, London, Behaven, 1993.

ZEMIN, Jiang, Reforma e Construção da China, Rio de Janeiro, Record, 2002.

Enviado para publicação em novembro de 2011.

Aceito para publicação em dezembro de 2011. 